\title{
整
}

\section{From Chrysostom to Luther: The roots of magisterial office in Martyr Vermigli's political theology}

\author{
Andries W.G. Raath \\ Department of Constitutional Law and Philosophy of Law \\ University of the Free State \\ BLOEMFONTEIN \\ E-mail: raathA.RD@mail.uovs.ac.za
}

\begin{abstract}
From Chrysostom to Luther: The roots of magisterial office in Martyr Vermigli's political theology

Peter Martyr Vermigli played a key role in developing and formulating the Reformational version of the political covenant for legitimating the political order. Three important perspectives shaped Vermigli's covenantal views: first, St. John Chrysostom's idea of political office; second, Luther's work on the divine origin of magisterial government and third, Heinrich Bullinger's commentaries on the Biblical covenant. These perspectives were integrated by Vermigli into an influential paradigm of covenantal politics. The impact of the ideas emanating from Vermigli's theologico-political federalism was not limited to the 16th-century Reformation, but also exerted considerable influence on the development of political contractarianism in $17^{\text {th }}$ - and 18th-century liberalism. In this contribution the emphasis is on Chrysostom's and Luther's contributions to Vermigli's political theology.
\end{abstract}

\section{Opsomming \\ Vanaf Chrysostomus tot Luther: die wortels van die politieke owerheidsamp in Martyr Vermigli se politieke teologie}

Petrus Martyr Vermigli het 'n sleutelrol in die ontwikkeling en formulering van die Reformatoriese weergawe van die politieke verbond ter legitimering van die politieke orde gespeel. Drie belangrike perspektiewe het Vermigli se sienings oor die verbond gevorm: eerstens, Johannes Chrysostomus se idee van die owerheidsamp; tweedens, Luther se werk oor die goddelike oorsprong van politieke regering en derdens, 
Heinrich Bullinger se kommentare oor die Bybelse verbond. Hierdie perspektiewe is deur Vermigli in 'n invloedryke paradigma van verbondsmatige politieke teorie geïntegreer. Die invloed van die idees wat uit Vermigli se teologiese-politiese federalisme voortgespruit het, was nie slegs tot die 16de-eeuse Reformasie beperk nie, maar het ook 'n impak op die ontwikkeling van die idee van politieke kontraktering in die 17de en 18de eeu gehad. In hierdie artikel val die klem op Chrysostomus en Luther se bydraes tot Vermigli se politieke teologie.

\section{Introduction}

The past fifty years have witnessed an upsurge in research on the theology of Peter Martyr Vermigli. ${ }^{1}$ In a few instances comments on Vermigli's political views have also been published. 2 However, the sources of Vermigli's political theology have not received the attention they should have. ${ }^{3}$ Over a period of almost fifty years three important works on the origins of Vermigli's political views have appeared. Commenting on the Christian sources of Peter Martyr Vermigli's political theology, Robert Kingdon observes that Vermigli's intellectual position was "seldom strikingly original" and often runs closely parallel to the positions of Bucer, Calvin and Bullinger (Kingdon, 1980:IV). He adds that Vermigli refused "ever to follow such Protestant leaders as Luther in decisively rejecting this background" (Kingdon, 1980:IV). Kingdon points out that Vermigli's comments on politics often include allusions to the classic patristic commentaries, above all the Homilie number 23 by St. John Chrysostom on Romans 13 (Kingdon, 1980:V). Kingdon also alludes to the fact that Vermigli associated himself closely with other leaders of the Reformation, most obviously Martin Luther, also a former member of the Augustinian order (Kingdon, 1980:VII). To these sources Kingdon adds Vermigli's use of contemporary constitutional arrangements (Kingdon, 1980:X).

1 See e.g. McLelland (1957), McNair (1967), Anderson (1975), Donnelly (1976), McLelland (1980), Donnelly, Kingdon and Anderson (1990), Donnelly, James III and McLelland (1994) and James III (1998). See also Donnelly and Kingdon (1990). According to Donnelly scholarly work on Martyr peaked in the early 1970s, abated somewhat in the 1980s, then gained empetus again in the 1990s (Preface).

2 The most important of these are Anderson (1978:157-200) and Kingdon (1980).

3 Although Vermigli's main works on politics have been identified and commented on, the sources of his political views have not received the required attention. 
In his seminal work on Martyr Vermigli's political views, Anderson specifically mentions the fact that Vermigli read Bullinger, Melanchthon and Bucer on Romans (Anderson, 1978:167); that Vermigli wrote to Calvin and Bullinger from Strasbourg in the period from 1553 to 1556 (Anderson, 1978:173) and that he also wrote to Thomas Sampson opposing a document jointly prepared by Sampson and Ponet in 1554, The Humble and unfained confession of the beliefe of certain poor banished men, published under the nom de plume of Dorcaster (Anderson, 1978:174). From Anderson's research it appears that according to Josiah Simler, Martyr, while in Naples, read Zwingli's De Vera et Falsa Religione (1525), but that it is impossible to trace other sources for Martyr's political comments beyond those clear references in his text (Anderson, 1978:179). This leads Anderson to the conclusion that Vermigli used Johannes Brentz for his Old Testament lectures (Anderson, 1978:180-181) and that Bullinger's influence must be kept in mind, since Vermigli used Bullinger's commentary on Romans and also joined him in Zurich during July 1556 (Anderson, 1978:182).

In a recent contribution on the intellectual roots of republicanism in Vermigli's theology, Giulo Orazio Bravi deals with the Biblical roots and the secular origins of some of the ideas in Vermigli's political thought (Bravi, 2002:119-141). Focusing on the doctrine of resistance by lower authorities to those higher in office, when these do not keep within their spheres of authority, Bravi remarks that Vermigli knew this doctrine from the works of Bucer, Zwingli and Calvin. 4

From these three commentaries the following conclusions may be drawn with regard to the Reformational sources used by Vermigli in formulating his views on political office and the basis of resistance to tyrannous authorities:

- The works of the Fathers, specifically Homilie 23 of St. John Chrysostom, played a significant role in providing Vermigli with the theoretical basis of the Biblical perspectives on magisterial office; Luther's views on political office did influence Vermigli's political theology in significant respects.

- Bucer, Zwingli and Calvin did exert some influence on Vermigli's formulation of the doctrine of resistance by lower authorities.

4 It is also important to note that in 1572 Hotman reminded Bullinger of Vermigli's views on resistance (Bravi, 2002:130, 131). 
- Bullinger contributed in some undefined respects to Vermigli's political thought.

- The sources of Vermigli's political theology were largely determined by the influences exerted during particular phases of his theological development.

An analysis of the development of Vermigli's political views confirms the fact that his political theology went through different stages, each reflecting the impact of particular theological and political sources. Broadly speaking, the main sources impacting upon the major stages of Vermigli's political development are threefold: firstly, St. John Chrysostom's commentary on Romans 13; secondly, Martin Luther's views on magisterial office and thirdly, the influence exerted by Heinrich Bullinger's theologico-political federalism.

\section{Martyr Vermigli's reliance on St. John Chrysostom's and Martin Luther's views on magisterial office}

\subsection{Chrysostom's commentary on Romans}

The Reformational approach to politics was shaped in fundamental respects by St. John Chrysostom's (344-407) Homilies on the Epistle of St. Paul the Apostle to the Romans (Chrysostom, 1996). 5

5 All references to Chrysostom's commentary on Romans 13, Homilie 23 (hereafter cited as Homilie 23), are to this source, except where otherwise indicated. References to Chrysostom's In Epist. Ad Rom. Cap. XIII , Book IV and his other works in Latin are to the texts in Sancti Patris Nostri Joannis Chrysostomi Archiepiscopie Constantinopolitani Opera Omnia in Duodecim Tomos distributa, Quorum Sex Priores Opuscula Ejus Varia, Sex posteriores in Novi Testamenti libros Homilias complectuntur. Graece \& Latine conjunctium edidit, ex Bibliotheca Christianissimi Regis, \& melioribus undique conquisitis exemplaribus recensuit, \& Parisiis Anno MDCIX. in lucem emisit FRONTO DUCAEUS Societatis JESU Theologus. Juxta cujus exemplar NOVA HAEC EDITIO accurate recensita, emendata, \& in arctiorem modum coacta, nunc primum in Germania prodit, cum copiosis Indicibus, \& Privilegio Serenissimi Potentissimique Regis Poloniae, Tomus Quartus (Novum Testamentum) (Francofurti ad Moenum: BALTHASARIS CHRISTOPHORI WUSTII, Senioris, M. DC. XCIIX). No section of the New Testament has received so many comments as the Epistle to the Romans. Although there is no separate commentary by any of the Fathers on this Epistle, it has been explained, together with other sections of Scripture, by Origen in the third century; by Jerome, Chrysostom, and in part by Augustine, in the fourth; by Theodoret in the fifth; by Oecumenius in the tenth; and by Theophylact in the eleventh century. Generally speaking, Chrysostom remained an authoritative author to many of the Reformational authors. Martin Luther refers explicitly to the theological views of Chrysostom in at least thirty key instances, to his Homiliae in Epistolam ad Hebraeos twenty times and once to Homilia $X$ in Epistolam ad Romanos, besides the implicit application of Chrysostom's views in a number of instances. Calvin refers to Chrysostom in his commentaries on Romans in at least eight instances, and Baker (1980:xiv) observes that Bullinger was greatly 
In Homily 23, commenting on Romans 13:1-10, Chrysostom's views on the divine origin of political government anticipated some of the most widely held interpretations of obedience to political officebearers. In particular Chrysostom's views on Romans 13:1 ("Let every soul be subject unto the higher powers"), echoed in the works of early Reformers like Martin Luther. The theme dominating Chrysostom's political views in Homily 23 is obedience to political authorities. 6

Chrysostom followed a clear line of argument in his commentary on St. Paul's appeal to subjects to obey political authorities. ${ }^{7}$ Firstly, according to Chrysostom, the command contained in Paul's call to subjection to political authority, is expressive of the fact that it was not for subversion of the commonwealth that Christ introduced His laws, but for the better ordering of it. Christ introduced His laws to teach men not to be taking up unnecessary and unprofitable wars ${ }^{8}-$ if it is right to requite those who injure us "with the opposite", how much more is it our duty to obey those who are beneficent towards us. This demand also applies to priests and monks, and not only to men of secular occupation. 9 Apostles, evangelists and prophets are

influenced by the Church Fathers, particularly Jerome, Chrysostom and Augustine.

6 On the political context within which Chrysostom worked and his political thought in general, see Dagron (1974), Festugière (1959), Kelly (1995) and Ritter (1972). For other works in which Chrysostom reflected, albeit briefly, on political issues, see Migne (1857-1866) (the Seventeenth and Twenty First Homilies and the Eleventh Homily on the Acts of the Apostles. Vol. 60) and Field (1845-1862) (the Twelfth Homilie on 1 Timothy).

7 O'Donnovan and O'Donnovan (1999:90) describe Chrysostom as one of the most careful readers of the biblical text that the patristic church produced. The exposition of Romans, from the Antioch years, is a fine example. His insistence that Paul thought God appointed government as such, not each and every government, illustrates his care with important nuances of meaning. This author attributes to Chrysostom's analysis of Paul's argument, two parallel trains of thought, one presenting government as a deterrent to crime, the other as a beneficial support for virtue. Though probably not right as it stands, it is a thoughtful reading worthy of serious engagement. "Yet", according to O'Donnovan and O'Donnovan (1999:90), "both interpretative moves accord well with the Greek-Christian predisposition to find in government a direct mediation of God's beneficial providence".

8 Chrystostom, M.DC.XCIIX: vol. IV: fol. 315 D: "Facit autem hoc ideò, ut ostendat Christum leges suas non ad hoc induxisse, ut politias evertat: sed ut ad melius instituat, \& ut pariter doceat, superflua \& inutilia bella non esse suspicienda."

9 Chrysostom, M.DC.XCIIX: vol. IV fol. 315 A: "Interea verò eas rationes quas commemoravi, non movet, sed eas quae potestatibus ex debito obedire jubent, ostendens quòd ista imperentur omnibus, \& Sacerdotibus \& Monachis; non solum 
equally subject to political authority, inasmuch as this is not subversive of religion, because to Chrysostom, all power emanates from God to prevent "that all things should not just be carried on in one confusion" (Chrysostom, 1996, Homilie 23:915-916). 10 Chrysostom's first argument, therefore, implies that political government is a necessary and essential institution.11

Chrysostom's second line of argument is that God in his wisdom provided for some to be rulers and others to be ruled. God provided for many forms of government and forms of subjection, including that of ruler and ruled - political government is a divine institution and not of human invention. Alluding to the organic metaphor of the human body, Chrysostom states that similar to the limbs forming the human body not having "equal honour", God also provided for some men to have lesser and others greater honour, as forms of "godly subordination",12 for "anarchy, be where it may, is an evil, and a cause of confusion" (Chrysostom, 1996. Homilie 23, 916).13

secularibus: id quod statim in ipso exordio declarat, cum dicit: omnis anima potestatibus supereminentibus subdita sit, etiam si Evangelista, si Propheta, sive quisquis tandem fueris."

10 See Chrystostom, M.DC.XCIIX: vol. IV: fol. 315 C: "Quòd enim principatus sunt, quòd hi quidem imperant, isti verò subjecti sunt, quodque non simpliciter ac temerè cuncta feruntur, nec fluctuum instar populi huc atque illuc circumaguntur, divinae sapientiae opus esse dico." Chrysostom emphasises the fact that St. Paul does not refer to the ruler as such, but to the power, by saying "for there is no power but of God", adding: "the powers that be, are ordained of God" ("Propterea non dicit: Non enim princeps est, nisi à Deo sed de re ipsa differit, dicens: non enim potestas est, nisi à Deo. Quae verò sunt potestates, à Deo ordinatae sunt").

11 Already Fathers of the third century, like Origin (185-230-254) and Dyonysius (200-265):172, related obedience to magistracy to serving the public good.

12 See Crystostom, M.DC.XCIIX vol. IV: fol. 315 E: "Quoniam enim honoris ac conditionis aequalis pugnas ac dissidia plerumque inducit, multos fecit principatus, multásque subjectionis: utpote viri \& uxoris suae, filii \& patris, senis \& adoloscentis, servi \& liberi, principis \& subditi; praeceptorisque ac discipuli."

13 Chrysostom, M.DC.XCIIX: vol. III: fol. 546 D, explains the necessity for civil magistracy as follows: "Hic rursus loquitur de alio genere providentiae, nempe de principibus, quod Paulus quoque in epistola ad Romanos ponit sapientissimè ostendens hoc ... opus Dei providentiae, in eos, qui magistratus gerunt, \& in eos, qui illis parent, universum divisisse. Dei enim minister est tibi, inquit, in bonum. Si hoc autem sustuleris, universum interit. Si enim cùm nunc sunt pricipes \& magistratus, multique sunt in eis corrupti ac depravati, tantus tamen rei est usus, ut etiam cùm mali sint, magna ex eis capiatur utilitas: cogita apud te, si ii, quibus sunt crediti magistratus ... qùam benè cum genere humano ageretur. Sed magistratus quidem constituere, fuit Dei opus: quòd autem improbi ad eos provehantur, \& eis, non ut decet, utantur, est hominum improbita. Dicit ergo, oportere magnas Deo gratias agree, quod sint \& Reges, \& Judices. Certo enim ordine \& modo constitutae hominum administrationis curam gerens, \& ne plus 
Because political authority is a divine institution ${ }^{14}$, Chrysostom appeals to believers in his statement that being subject to earthly rulers does not mean being made cheap and despicable, but actually means being subjected to God, "for it is to Him, that he who subjects himself to authorities is obedient" (Chrysostom, 1996. Homilie 23, 916).15 Furthermore, it is not by way of favour that believers obey them, but by way of debt."16 Believers should, therefore, not be ashamed at such subjection, "(f)or it is no common punishment that He will exact of thee, if thou disobey, but the very greatest; and nothing will exempt thee, that thou canst say to the contrary, but both of men thou shalt undergo the most severe vengeance, and there shall be no one to defend thee, and thou wilt also provoke God the more" (Chrysostom, 1996. Homilie 23, 917). ${ }^{17}$

quàm ferino ritu multi viverent, providens, veluti quandam currus regendi artem, \& navis gubernandae scientiam, magistratus \& regna largitus est. Si ergo sis princeps, aut magistratum geras, benigno \& clementi Deo age gratias, quòd tuae ostendendae curae \& diligentiae tanta tibi data sit occasio."

14 Already Irenaeus (1996:120-202):1106 rejected the notion that civil government and political authority are not appointed of God, but of the devil.

15 Augustine (1996a:557), in his Commentary on Psalm 62, emphasises the principle that political government and being Christians in the Kingdom of God need not be mutually exclusive: "For how many faithful, how many good men, are both magistrates in their cities, and are judges, and are generals, and are counts, and are kings? All that are just and good men, having not anything in heart but the most glorious things, which of Thee have been said, City of God".

16 Chrysostom (1996, Homilie 23:917): "For in this way he was more likely to draw the governors who were unbelievers to religion, and the believers to obedience. For there was quite a common report in those days, which maligned the Apostles, as guilty of a sedition and revolutionary scheme, and as aiming in all they did and said at the subversion of the received institutions. When then you show our common Master giving this in charge to all His, you will at once stop the mouths of those that malign us as revolutionists, and with great boldness will speak for the doctrines of truth. Be not ashamed, he says, at such subjection. For God hath laid down this law, and is a strong avenger of them if they be despised."

17 Chrysostom, M.DC.XCIIX: vol. VI: fol. $704 \mathrm{~A}$, deals with obedience to magistrates as follows: "Nam qui magistratibus obedit, ille non magistratibus, sed Deo, qui lege ejusmodi res sancivit, obedit: \& qui illis non obtemperat, Deo repugnat. Non enim est potestas, inquit, nisi à Deo. Etenim magistratus esse, \& hos quidem imperare, alios verò subditos esse, \& non promiscuè omnia iustar fluctuum ferri, populis huc illuc circumactis, divinae sapientiae opus est. Ideo horum quoque, si contemnantur, ecerrimus vindex est. Nec enim vulgarem poenam de te sumet, si istos spreveris, sed longè maximam. Nec quicquam te contradicentem eripiet: sed \& apud homines gravissimum subibis supplicium, \& Deum vehementùs irritabis." Also see Chrystostom, M.DC.XCIIX: vol. II: fol. 749 D. Chrysostom, M.DC.XCIIX: vol. IV: fol. 318 E explains God's wrath for transgressing this command: "Nec quicquam erit quod contradicentem eximat, quo minus \& ab hominibus gravissimum feras suplicium. Et nemo siquidem tutabitur, \& Deum 
St. Paul uses not only arguments of fear to persuade believers to obedience, but also other arguments contained in the wording of the text of Romans 13:3 ("For rulers are not a terror to good works, but to evil.") Having rebuked those who resist political authorities, St. Paul uses milder reasons to persuade believers to obedience to political rulers: God does not punish a person who is doing well, neither "is he terrible to a person who lives in the practice of virtue" (Chrysostom, 1996. Homilie 23, 917). God even praises the believers, making them friends with the ruler: God makes "wrath unmeaning" (Chrysostom, 1996. Homilie 23, 917).18

Chrysostom's appeal to believers in his second argument forms the background to his third argument: God makes virtue easier by chastising the wicked, by benefiting and honouring the good, and by working together with the will of God (Chrysostom, 1996. Homilie 23, 918). ${ }^{19}$ Political authorities sit in judgment in cases of subjects being rapacious and grasping, and so work together with us, commissioned by God for this end. Therefore, a political ruler is to be reverenced "because he (the ruler) was commissioned by God, and because it was for such an object" (Chrysostom, 1996. Homilie 23, 918). God even shapes things so that political authorities carry out God's law, thereby being the cause of so many good things (Chrysostom, 1996. Homilie 23, 918). St. Paul's appeal to be subject to political authority, not only for wrath but also for conscience' sake,20 means that subjects do not only suffer God's wrath if they resist political authority, but also receive peace and God's blessings if they subject themselves (Chrysostom, 1996. Homilie 23:918-919). States receive countless blessings through these authorities - if

ipsum magis irritabis. Quae quidem omnia subindicans, dicit: Qui autem restiterint sibiipsis judicium accipient."

18 See Chrysostom, M.DC.XCIIX: vol. IV: fol. 318 A: "Vides quomodo ipsum magistratui familiarem \& amicum faciat, dum ostendit eum illius etiam laudatorem, si bene egerit, constitutum? Vides quo modo fastum evacuaverit."

19 To Chrysostom this idea is contained in Romans 13:4: "For he is the minister of God to thee for good." See Chrysostom, M.DC.XCIIX: vol. IV: fol. 318 B: "Nam \& aliàs faciliorem tibi virtutem facit, quòd $\&$ malos quidem punit, \& bonos verò beneficiis afficit \& honore, voluntatique Dei cooperatur: unde \& ministrum Dei illum vocat."

20 Romans 13:5: "Wherefore ye must needs be subject, not only for wrath but also for conscience' sake." In Chrysostom, M.DC.XCIIX: vol. IV: fol. 319 A, Chrysostom expresses himself as follows on this text: "Quid est, non solùm propter iram? Non solùm, inquit, quòd Deo non subditus adversaries, neque quòd maxima tibi ipsi mala \& Deo \& ab hominibus concitas? sed quòd \& inmaximis tibi benefacit magistratus, dum \& pacem, \& administrationem politicam procurat." 
these were to be removed, all things would go to ruin, and "neither city nor country, nor private buildings, nor anything else would stand, but all the world will be turned upside down, while the more powerful devour the weaker" (Chrysostom, 1996. Homilie 23:919). ${ }^{21}$ The reasons why believers are to pay tribute, says Chrysostom, are manifold. From old, all men have come to an agreement that governors should be maintained by their subjects, because to the neglect of their own affairs, they take charge of the public "and on this they spend their whole leisure, whereby our goods also are kept safe" (Chrysostom, 1996. Homilie 23:919). Not only do believers experience many external benefits by subjecting themselves to political authorities, but obedience is moreover commanded by God. Furthermore, believers should pray in the behalf of such authorities (Chrysostom, 1996. Homilie 23:919). In no small degree do political rulers contribute to the settled state of the present life, "by keeping guard, beating off enemies, hindering those who are for sedition in the cities, putting an end to differences among any" (Chrysostom, 1996. Homilie 23:920).22

Chrysostom's fourth argument is contained in his commentary on the text of Romans 13:7-10 - not only should money be paid to all higher authorities, but also honour and fear.23 In this context, "fear" to Chrysostom means rendering what is due - it is not a favour to render fear, since it is a matter of what is due (Chrysostom, 1996. Homilie 23:920). If subjects do not do this, they will be punished as

21 He adds: "And so even if some wrath were not to follow man's disobedience, even on this ground thou oughtest to be subject, that thou mayest not seem devoid of conscience and feeling towards the benefactor." See Chrysostom, M.DC.XCIIX: vol. IV: fol. 319 A-B: "Nam innumera bona civitatibus per magistratus proveniunt, quae si sustuleris, omnia simul pessum ibunt: ita ut neque urbes, neque agri, neque domus, neque forum, aut aliquid aliud consistere queant, sed omnia simul subvertantur, potentioribus imbecilliores impunè devorantibus."

22 Chrysostom implicitly refers to 1 Timothy $2: 1,2$. The Church Father Dionysius, in the third century alluded to the metaphor of political office-bearers acting as fathers and teachers to the people (see Dionysius, 1996:398). Augustine (1996b:76), quoting Cicero, De Republica, states the principle that it is by decision of magistrates and "well-informed justice" that our lives ought to be judged. Irenaeus (1996:1107) states: "Earthly rule, therefore, has been appointed by God for the benefit of nations ....".

23 Also see his remarks in Chrysostom, M.DC.XCIIX vol. V: fol. 594 C; "Porro formidabilia quoque peccatoribus esse, quemadmodum pigris puerulis nomina magistrorum, audi quo pacto Paulus screbens ad Galatas subindicarit." 
obstinate, 24 for God willed that a ruler who has his place marked by Him, should have his own power: "For it is not from honouring that the lowering of self comes but from dishonouring him" (Chrysostom, 1996. Homilie 23:920). Chrysostom adds: "And the ruler will treat thee with greater respect, and he will glorify thy Master owing to this, even if he be an unbeliever" (Chrysostom, 1996. Homilie 23:920). Love, to Chrysostom, is the mother of all good deeds, who is also productive of every virtue;25 love implies a continuous debt; it always has to be rendered - it is the nature of a debt that one keeps giving and owing always (Chrysostom, 1996. Homilie 23:921). Returning to the organic metaphor of the human body, Chrysostom states that to love one another is a debt, because "we are members one of another" (Chrysostom, 1996. Homilie 23:921). 26 If love leaves us, the whole body is rent in pieces. The beginning and end of virtue is love: "This it has for its root, this for its groundwork, this for its summit" (Chrysostom, 1996. Homilie 23:921). Love works both virtues: abstinence from evils, and the working of good deeds 27 thus the request: let us then love one another, since in this way we shall also love God, who loves us (Chrysostom, 1996. Homilie 23:922). ${ }^{28}$

24 Chrysostom, M.DC.XCIIX: vol. IV: fol. 319 C: "Nihil enim gratuitò dat, qui hoc fecerit. Debitum siquidem est res ista. Quòd si non feceris perfidi poenas dabis. Neque sanè putes Christianae philosophiae dignitatem extenuari ac laedi, si praesente principe honoris gratia exsurrexeris, sive caput detexeris." The AnteNicene Father Arnobius (born c. 297) pointed out that speaking evil about kings was punishable as treason and degrading magistrates should be followed by the severest punishment (Arnobius, 1996:909).

25 Chrysostom, M.DC.XCIIX: fol. 322 C-D: "Virtutis enim principium ac finis est dilectio. Hanc habet radicem, hanc materiam, hunc verticem."

26 During the Renaissance Erasmus, as early as 1516, alluded to the organic metaphor of the human body to explain the duty of the Christian prince to act in the public interest. Erasmus (51:1516, 1997 [1516]) (ch. 1, p. 51[1:51]). Also see 1:43: "Since the state is a kind of body composed of different parts, among whose number is the prince himself ..., it will be important to maintain a balance that is for the good of them all, and does not result in one or other becoming plump and vigorous while the rest are weakened." Also see 1:39, 40 n. 64.

27 See Chrysostom, M.DC.XCIIX: vol. IV: fol. 322 A: "Vides quomodo utramque virtutem habeat dilectio? nimirum ex uno latere abstinentiam à malo."

28 See Chrysostom, M.DC.XCIIX: vol. IV: fol. 322 C: "Diligamus itaque nos invicem, tanquam \& eadem dilectione diligentem nos Deum dilecturi: Apud homines quidem si eum quem aliquis alius diligit dilexerit, repugnabit illius amator: hîc verò dignatur te Deus amoris sui communione, ac non communicantem odit." 
Chrysostom's remarks in Homilie 23, almost exclusively limit the commentary on Romans 13:1-10 to the duties of subjects towards their political rulers. ${ }^{29} \mathrm{He}$ does not venture into the field of the limits of the powers of rulers, neither does he express himself on the duties of rulers towards their subjects. ${ }^{30}$ Furthermore, Chrysostom is much more reserved than both Eusebius and Irenaeus with regard to disobedience to political authority. ${ }^{31} \mathrm{His}$ analysis of the true signs of magistracy, however, implicitly means that power wielded by rogues and tyrants would not amount to the lawful exercise of magisterial power.

It was Martin Luther, at the beginning of the Protestant Reformation, who made a sincere effort to address these same issues from a

29 In some of the other Homilies of Chrysostom, O'Donnovan and O'Donnovan (1999:90), identify a matured perspective on office, in so far as Chrysostom approaches church-state conflict, not as a conflict of societies but as a conflict of ruling offices. No such perspectives appear from Chrysostom's analysis in Homilie 23. The reason why Chrysostom emphasises obedience rather than power, appears to be connected to O'Donnovan's observation (at 91) about the "aesthetic" of Christian government in Chrysostom's work on church-state conflict: the drama of overcoming wrath with mercy, subduing political and military power with spiritual power, thereby providing "a kind of ritual legitimation of the governing authorities in a Christian society."

30 Chrysostom, M.DC.XCIIX: vol. V: fol. 657, under the heading "Magistratus vera insignia", Chrysostom did reflect briefly on the attributes of magistracy: "Nam illic quidem eq quae tribuuntur, una cum hac vita finiuntur, \& tumultus plena sunt ac turbis redundant: hic veronihil tale, sed \& securitas omnis, \& honor à turbis immunis est, \& magistratus qui nunquam finiuntur, nec ipsa morte interrumpuntur, sed tum temporis tutiores fiunt. Nolo enim mihi commemores eum qui sedeat in curru, supercilia attollat, multoque sit satellitio cinctus, neque cingulam \& vocem praeconis: nolo mihi magistratum inde designes sed ab animi statu, si affectibus imperet, si vitia subigat, si non invidia tabescat, si non inanis gloriae perturbatione distrahatur, si egestatem non metuat \& tremat, si non in deterius mutationem, si hoc timore non exanimetur. Talem mihi magistratum ostende, hoc enim est gerere magistratum. Quod si hominibus quidem imperet, sed perturbationibus serviat, hunc inter homines insimo genere servitutis facile dixerim esse subjectum." O'Donnovan and O'Donnovan (1999:91), however, do detect elements of thought on the limits of governmental power in Chrysostom's political writings.

31 Eusebius quotes the martyr Polycarp who maintained that obedience to "princes and authorities" depends upon their being "ordained by God" and added that Christians had been taught to render to princes and authorities the honour that is due, so long as it did not injure them (Eusebius, 1996:270). In his Apologetic, Chapter 17, Tertullian (1996:150-240), propounded the view that "(W)e (Christians) can render service, even 'to magistrates and powers,' after the example of the patriarchs and the other forefathers, who obeyed idolatrous kings up to the confine of idolatry." 
Scriptural point of view. 32 Reverting to Chrysostom's perspectives on the theological basis of civil authority, Luther, strongly propounding the concept of magisterial office, added criteria for the limitation of civil authority. At the centre of Luther's political theology are his perspectives on the nature and limitations of office.

\subsection{Martin Luther and the idea of magisterial office}

Although Luther's thought on law and politics proceeded through various stages of his life, it is possible to extract the general framework of his ideas on political office, which remained basically unchanged. In similar vein to Chrysostom, Luther advances four main arguments purporting to justify subjection to magisterial office. Along much the same lines as Chrysostom, Luther, in his commentary on Romans 13 , as early as $1515 / 1516$, stresses the obedience of subjects to magisterial authorities. ${ }^{33}$ Commenting on Romans 13:1-7, Luther remarks that in contradistinction to the Jewish conception, the Apostle teaches that Christians must subject themselves also to the wicked and to unbelievers (Luther, 1976:179 - hereafter cited as CR). ${ }^{34}$ Even though rulers may be wicked and unbelieving, their governmental power is good in itself and of God. Therefore, Christians should not, under the pretence of Christian religion, refuse to obey men in authority, even if they are wicked. To Luther, the Apostle therefore commands that Christians should honour the power of governments and not use their liberty of grace as a cloak for their maliciousness. ${ }^{35}$

32 Many separate expositions on Romans have been published by the Reformers, besides a learned introduction by Luther and Notes or Scholta by Zwingli and Melanchthon.

33 Berggrav (s.a.:301, 302), rightly emphasises that subjects' obedience to magisterial authorities does not imply two kinds of obedience, because to Luther all powers are attributed to God alone. In his commentary on Psalm 101(1535) Luther remarks that at the very beginning of the Psalm the Psalmist advises kings and princes to praise and thank God if they have pious servants and good management at home or at court. It follows, then, that they should learn to know that circumstances like these is a special gift and not a matter of their own wisdom or ability (see Luther, 1956; commentary on Psalm 101). The year 1517 also saw Erasmus of Rotterdam's publication of the paraphrase on the Romans.

34 All references to Luther's commentary on Romans are to this source. Luther refers to 1 Peter 2:13-15 on this point. Luther's commentary on the Epistle to the Romans is preceded by a very useful introduction, much praised in Reformational circles, and which has attained the name of the "golden preface".

35 He has in mind the text in 1 Peter 2:16: "As free, and not using your liberty for a cloak of maliciousness, but as servants of God" (at 179-180). 
Referring to the preceding chapter, Luther observes that in this chapter the Apostle taught that Christians should not throw into disorder the institution of the Church. In chapter 13 Luther teaches that Christians should not violate the temporal government, for both of these institutions are of God - the former serves the guidance and peace of the inner (spiritual) man and his concerns; the latter serves that of the outward (earthly) man and his concerns (Luther, 1976:180). J. Theodore Mueller remarks that, in essence it means that to the Church the state and civil government are necessary and essential institutions (Luther, 1976:180): temporal powers have the duty to protect their subjects, to punish thievery, robbery and adultery and to protect the good.36 Government is a sign of divine grace, of the mercy of God, who has no pleasure in murdering, killing and strangling. If God left all things "to go which way they would, as among the Turks and other nations, without good government, we should quickly dispatch one another out of this world" (Luther, Table Talk paragraph 755:331; see Luther, 1996. ${ }^{37}$ Magistracy, therefore is a necessary state in the world (Luther, TT, paragraph 755:32; see Luther, 1996). Like all other forms of authority, magisterial discipline is not only good, but also very necessary and without which nothing can be well done (LW, St. Paul's Letter to the Galatians (LG), 203). Civil magistracy enforces the law outwardly. This is the politic use of the law, which serves to bridle those who are "rude and untractable" (LW, LG, 289). The reasoning behind the need for magisterial authority, to Luther, is contained in the arguments in his Commentary on Galatians: God has ordained magistrates, parents, teachers, laws, bonds and all civil ordinances that, if they can do no more, yet at the least they may bind the devil's hands, "that he rages not in his bond slaves after his own lust" (LW, LG, 289; see Luther, 1956). 38 A magistrate is present with his bonds and chains; that is to say, with his laws, binding his hands and feet, that he run not headlong into all mischief. If he is not bridled in this fashion, "then he loseth his head" (LW, LG, 289; see Luther, 1956). Civil restraint is therefore very necessary for public peace as well as for the preservation "of all things", and especially "lest the course of the Gospel should be

36 Luther's Works (LW) (1956), Vol. 1, A Treatise on Good Works, together with the Letter of Dedication (GW) (1520), 137-223, at 206. All citations of Luther's works $(\mathrm{LW})$ are to the collection in the Ages Digital Library Collection: Books for the Ages (Albany, OR (USA), Version 1.0 (1997).

37 All references to Luther's Table Talk (TT), are to this source.

38 He adds: "Like as therefore they that are possessed, in whom the devil mightily reigneth, are kept in bonds and chains lest they should hurt other ...". 
hindered by the tumults and seditions of outrageous men" (LW, LG, 289:289). Furthermore, if women would be men, if the sons would be the fathers, the servants the masters, the subjects the magistrates, there would be nothing else but confusion of all estates and of all things. God therefore provided for various forms of subjection (LW, LG, 289:369). Authority was instituted by God and to carry out His sovereign rule, God employs human institutions to promote His will:

This is why the worldly kingdom is set up over 'the flesh', over the outward conduct of men, and over that alone. Its function is to maintain order, to promote the good, and to protect law and spiritual freedom. The church is not to invade this domain with worldly means, because both of these servants have as their function the carrying out of the will of God. They are consequently united in the common task which God designs ... (Berggrav, s.a.:303).

In addition to the argument for the need of civil magistracy, Luther identifies magisterial authority as one of the essential forms of subjection in human society. In his Watchwords for the Warfare of Life (WW), Luther appeals to true Christians to obey, for God's sake, parents, magistrates, "and those who have the care of souls, masters and teachers" (LW, WW, 64; see Luther, 1956).39 Although parents are to be honoured above all magistrates because they are the fountain and source of the Fourth Commandment (LW, WW, 130; see Luther, 1956), magistracy, to Luther, remains an important form of subjection, similar to all other forms of authority which are subject to Christ: "Christ is the sole and supreme Lord over all kings, princes and governors" (LW, Sermons (S), volume 7, 179).40 The exercise of faith, according to the Fourth Commandment, consists of the faithful performance of the duties of children toward their parents, of parents towards their children and of subordinates towards their superiors in the ecclesiastical as well as in the common civil sphere. Magisterial authority 41 is closely attached to

39 Starting with his comments on the Second Table of the Law.

40 Sermons on the Epistle Texts for Epiphany, Easter and Pentecost: Easter Sunday Second Sermon on Acts 13:26-39. Luther adds: "True, we should be obedient to parents and to civil authority, but not to the extent of disobeying the Lord, him who has created and subjected to himself emperors and magistrates equally with the lowliest of men."

41 By "authority" Luther means both great and small, emperor and councilman, prince and mayor. (See also Berggrav, s.a.:304.) 
the benefits flowing from magisterial office - without magistrates men would not eat and retain their daily bread; they would not keep a farthing (LW, Large Catechism (LC), 102). The basic principle Luther drives home, is that a prince, a magistrate, a preacher, a schoolmaster, a scholar and other persons with God-given authority are instruments by whom God governs and preserves the world (LW, LG, 114).42 Although subjects must honour and pay reverence to these "outward veils" or persons as his instruments, these authorities are not to be feared in questions touching religion, conscience, the fear of God, faith, or the service of God (LW, LG, 44). 43

Magistracy being a form of subjection instituted by God, magistrates are therefore instituted by God; being instituted by God, honouring magistrates results in many blessings. Commenting on the passage of Matthew 22:15-22, Luther stresses the fact that the various forms of government instituted by God are good. This pericope, to Luther, means that God praises earthly government and commends man to render unto it what is due to it. It is God's desire that there should be magistrates, princes and masters, whom we are to obey, "be they what they may and what they list." Neither should we ask whether they possess and exercise government and authority justly or unjustly. We should only pay heed to that power and authority which is good, for it is ordered and instituted by God (LW, S, volume 5, 269).44 Reverting to the benefits bestowed by magisterial institutions, Luther adds that government has also been ordained by God, that it may uphold general peace, "which thing done cannot be paid for by all the money in the world" (LW, S, volume 5, 271).45 All institutions of authority are subject to Christ, the sole and supreme Lord over all kings, princes and governors (LW, S, volume 7,

42 In other words, God's purpose with the worldly power is that it should be God's instrument: "This, and this alone, is the reason why it is every Christian's duty to be obedient to such power. It does not lie in the fact that the power itself merits or has the right to demand any obedience or respect. It receives it solely because it is a part of God's design" (Berggrav, sa:303). Berggrav also points out that Luther describes the correct attitude toward civil authority in religious terms (religiose venerari), because authority is instituted by God.

43 They are, therefore, mere "masks" or "veils". See Gritsch (1972:37-55, at 53).

44 Sermons on the Gospel Texts for the 13th to 26th Sundays After Trinity: Twenty Third Sunday After Trinity on Matthew 22:15-22.

45 Luther has in mind the uprising of the peasants, and the "damage, misery and woe" caused by the breaking of peace. 
179).46 Temporal government is preserved not only by laws and rights, but by divine authority: "tis God maintains governments, otherwise the greatest sins in the world would remain unpunished" (TT, 762:332). God, through the law, shows what his will is and how the evil should be punished. Since the law does not punish a potentate, prince or ruler, God will eventually call him to account and punish him (TT, 762:332). The institution of magistracy is the work of God even though men are evil. Therefore, magistracy does not cease to be the work of God, even though magistrates may abuse their power (LW, LG, 20).

Fourthly, in similar vein to the Church Fathers, Luther stresses obedience and subjection to magisterial authority. In 1525 Luther wrote to the magistrates of Dantzic that they should maintain discipline and prevent the mobs from taking control, because a lack of discipline led to magistracy being held in contempt, "whom God commands to be feared and honored" (LW, Letters (L) 116:169). In his sermons Luther paid particular attention to spelling out God's commands in relation to obedience to authority. Preaching on Titus 3:4-8, Luther admonishes the people: "Note that Paul here indicates the relation we sustain to God and man. He would have us obedient to magistrates and kind to neighbors" (LW, S, volume 6:117).47 In his Large Catechism (LC), Luther took pains in arguing for obedience to magistrates, because by the office of political rulers we have protection and peace and without them we could not eat and retain our daily bread:

Therefore they are also worthy of all honour, that we give to them for their office what we ought and can, as to those through whom we enjoy in peace and quietness what we have, because otherwise we would not keep a farthing; and that, in addition, we also pray for them that through them God may bestow on us the more blessing and good (LW, LC, 102).

Good Christians honour their parents, magistrates and ministers, as God has commanded, but children of the devil do not obey authority and do not serve or help them; they are disobedient to magistrates and show them no reverence, but speak evil of them; they accept no

46 Sermons on the Epistle Texts for Epiphany, Easter and Pentecost: Easter Sunday Second Sermon on Acts 13:26-39 (1559). Therefore, the fact that an individual is a lord or a prince, a father or a mother, a child or a subject, administers authority or obeys it, will not excuse him from being baptised and believing in Christ.

Second Christmas Sermon: early Christmas Morning Service on Titus 3:4-8. 
admonition, reproof, civility or honesty (TT, 575:267). Elaborating on the same principle, Luther, elsewhere in his Table Talk, states that magistracy is a necessary state in the world and to be held in honour; therefore we ought to pray for magistrates, who may easily be corrupted and spoiled (TT, 760:332). In his preface to the letter of St. Paul to the Romans, Luther remarks that in chapter 13, St. Paul teaches that one should honour and obey secular authorities. Luther includes this advice, not because it makes people virtuous in the sight of God, but because it ensures that the virtuous have outward peace and protection and that the wicked cannot do evil in undisturbed peace and without fear. It is therefore the duty of virtuous people to honour secular authority, even though they do not, strictly speaking, need it. Finally, St. Paul sums up everything in love and applies it all to the example of Christ: what Christ has done for us, we should also do and follow after him (LW, Preface to the Letter of St. Paul to the Romans (PR), 16). The distinction between the immediate and mediate rule of God in relation to the calling of magistrates, surfaces in Luther's commentary on St. Paul's Letter to the Galatians. When princes and magistrates call their subjects, then with assured confidence it can be stated against the devil and enemies of the Gospel that they are called by the command of men through the voice of men. This call implies the command of God through the mouth of prince or magistrate, these being true vocations ( $L W, L G, 36$ ). Not to yield honour, to be disobedient to magistrates, to covet another man's goods, his wife and such like are called by Luther "carnal sins" (LW, LG, 54). Elsewhere in the same commentary, he calls these sins "gross vices" (LW, LG, 59). Obedience to magisterial authority does not justify the committing of these sins. 48 Nevertheless, obedience to magistracy is the fruit of the Spirit.49 In addition, magistracy is a blessing, demanding fear, reverence and honour in the civil sphere.50 Disobedience to civil authorities does not proceed from the doctrine of the Gospel:

48 LW, LG, 223: "Wherefore thus teach we: O man, although thou fast, give alms, honour thy parents, obey the magistrate, etc., yet art thou not justified thereby. This voice of the law: 'Honour thy parents', or any other else, either heard or fulfilled, doth not justify."

49 LW, LG, 231: "Wherefore all the duties of a Christian man, as to love his wife, to bring up his children, to govern his family, honor his parents, obey the magistrate, etc. ... are the fruits of the Spirit."

50 LW, LG, 263: "For we put a difference between the corporal and the spiritual blessing, and we say that the emperor is blessed with a corporal blessing. For to have a kingdom, laws and civil ordinances, to have a wife, children, house and lands, is a blessing. For all these things are good creatures and gifts of God, but we are not delivered from the everlasting curse by this corporal blessing, which is 
When a man that is not imbued with the Spirit of God heareth this, by and by he is offended, and judgeth that the disobedience of subjects against their magistrates, that seditions, wars, plagues and famine, that the overthrowing of commonweals, kingdoms and countries, that sects, offences, and such other infinite evils do proceed altogether of the doctrine of the Gospel (LW, LG, 462).

Luther subsequently replies to the accusations that Christians destroy good works, by stating that they teach good works and other virtues better than all the philosophers and magistrates of the world, because they "adjoin faith in their doings" (LW, LG, 517). To obey a magistrate, is to serve one another through love (LW, LG, 525). The fact is, says Luther, that in the commonwealth, subjects are never as obedient to the laws of magistrates as they should be (LW, LG, 580). In his Treatise on Good Works (GW), Luther states that the third component of the Fourth Commandment is to obey the temporal authority. Men transgress this commandment in two ways: firstly, by lying to the government, deceiving it, and being disloyal "neither obey nor do as it has ordered and commanded, whether with their bodies or their possessions" - for even if a government does injustice, as the King of Babylon did to the people of Israel, yet God would have it obeyed, without treachery and deception; secondly, when men speak evil of the government and curse it and when men cannot avenge themselves and abuse the government with grumbling and evil words, publicly or secretly (LW, GW, 143). Political authorities are worthy of all honour, "that we give to them for their office what we have, because otherwise we would not keep a farthing" (LC, 102). Believers should pray to God for obedience, peace and harmony in their life with one another (LC, 102). Obedience to parents and to civil authorities does not extend to disobeying the Lord, "him who has created and subjected to himself emperors and magistrates equally with the lowliest of men" (LW, S, volume 7, 179). While good Christians honour their parents, magistrates and ministers according to God's commandments, children of the devil do not listen to their parents, they do not serve and help them; they are disobedient to magistrates and show them no reverence, but speak evil of them (TT, 575:267). The fundamental principle, to Luther, is basically that honour and reverence must be given to the magistrates, because God has thus commanded (LW, LG, 438).

but temporal and must have an end. Therefore we condemn not laws, neither do we stir up sedition against the Emperor; but we teach that he must be obeyed, that he must be feared, reverenced and honored, but yet civilly." 
Luther's major contribution to the development of a Reformational theory of civil magistracy beyond the theological perspectives of the Fathers was his theoretical analysis of the idea of office. By attaching the idea of office to the subject's duties of obedience to magisterial authority, Luther provided the first steps in Reformational circles towards developing the basic tenets of political legitimacy, grounded in the theological tenets of the Reformation. These basic tenets of political legitimacy enabled Luther to find a concept for integrating the duties of both rulers and subjects and to advance a more systematic approach to political resistance. Luther's idea of magisterial office was, however, largely limited to his studies on the New Testament, thereby mainly basing his views on New Testament perspectives on magistracy. The practical limitations of magisterial power described in the Old Testament went largely unnoticed in Luther's theology, which therefore tended to be politically idealistic and spiritualistic, rather than providing practical solutions to the issues of tyranny and abuse of power by political authorities. Luther's views on the idea of magisterial office did, however, open up possibilities for discerning political abuse.

As early as 1520 Luther advanced the idea of magisterial office in his Open Letter to the Christian Nobility of the German Nation.51 In this work Luther states that magisterial office has a "proper and useful place in the Christian community". Luther then strongly advances the principle that there is really no difference between laymen and priests, princes and bishops, "spirituals" and "temporals", except that of office and work, but not of "estate"; for they are all of the same estate.52 Referring to magisterial office in particular, Luther comments that temporal power should exercise its

51 This work is closely related to his tract on The Papacy at Rome: A Reply To The Celebrated Romanist At Leipzig. In a letter to Spalatin, dated before June 8th 1520 , Luther writes that he "minded to issue a broadside to churches and the nobility of Germany against the tyranny and baseness of the Roman curia". The two weeks immediately preceding the publication of his work On The Papacy was probably the time when the Open Letter was produced. In his work On Papacy, Luther expresses his desire for "kings, princes, and all the nobles" turning the "knaves from Rome out of the country and keep the appointments to bishoprics out of their hands". This necessitated clarity on the nature and essence of magisterial office in its relation to ecclesiastical institutions.

52 Already in his CR, 170, commenting on Romans 12:3-7, prior to 1520, Luther strongly emphasised the fact that although believers have one and the same faith, they "nevertheless possess a different measure of gifts". Elsewhere in this commentary (at 173) Luther criticises both political and ecclesiastical officebearers for ruling with "luxury and laziness, riches and pleasure, glory and honor, force and tyranny". He adds: "Only he can be diligent with respect to others who is unconcerned about himself." 
office without let or hindrance, regardless "whether it be pope, bishop or priest whom it affects; whoever is guilty, let him suffer."53

In his Large Catechism, Luther states the basic function of magistrates: by their office they have to protect the good and ensure peace (LW, LC, 102). In his Table Talk, Luther describes the essence of the duties of magistracy in terms of punishing the guilty and wicked malefactors (TT, 562:259). Expressing himself on the topic of princes and potentates, Luther elsewhere declares that princes and rulers should maintain laws and statutes; they should,

... above all, hold the Gospel in honour, and bear it ever in their hands, for it aids and preserves them, and ennobles the state and office of magistracy, so that they know where their vocation and calling is, and that with good and safe conscience they may execute the works of their office (LW, LC, 758:331).

When a magistrate punishes, God himself punishes (LW, LC, 758: 332). 54 In effect, it means that the office of magistracy is the work of God (LW, LG, 20 - preface to the first edition, 1535). 55 Magisterial office is a calling of God; a true vocation (LW, LG, 36). The implication is that magistrates (and all other authorities) must follow their vocation (LW, LG, 135). Luther returns to the basic principle once again - magistracy is an office to be executed by man (LW, LG, 190). 56 Being a vocation and a calling, every man must do that which his vocation and office require: pastors and preachers must teach the Word of God purely; magistrates must govern their subjects and subjects must obey their magistrates, so that every creature serves in its due place and order (LW, LG, 321), because there are many offices ordained by God (LW, LG, 367). 57 One office is not better than the other:

53 LW, An Open Letter to the Christian Nobility of the German Nation Concerning the Reform of the Christian Estate (cited as OL), 54.

54 The civil official's action is only God's when it is exercised by a lawfully constituted authority. See Berggrav (s.a.:306).

55 To Luther both the office and the functions pertaining to such office are Godgiven, even though individual officials are not always conscious of these things. See Berggrav (s.a.:306).

56 Luther states: "For these things are not taken from him: generation, civil government, household management, are not done away, but they are confirmed by these sayings; which the sophisters have falsely applied to spiritual qualities."

57 In effect this means that man is to be obedient to all authority which has been instituted by God, whether the persons exercising the authority are good or bad. 
No godly man thinketh the office of a magistrate to be better in the sight of God than the office of a subject; for he knoweth that both are ordained of God and have the commandment of God. $\mathrm{He}$ distinguisheth not between the office or work of a father and of a son, a schoolmaster and a scholar, a master and a servant, etc.; but he confidently declareth that both are pleasing to God, if they be fulfilled in faith and obedience towards God. In the sight of the world, no doubt, these kinds of life and their duties are unequal; but this external inequality nothing hindereth the unity of the Spirit, whereby all think and believe the same concerning Christ, namely, that through him alone we obtain remission of sins and righteousness" (LW, LG, 529).

Therefore, wherever men perform their respective vocations and obey Christ, they perform saintly activities. 58 The vocation or calling of the various authorities has a restrictive effect: if magistrates, householders, servants, schoolmasters, scholars, etcetera abide in their respective vocations and do their duties diligently and faithfully, not troubling themselves with those works which do not pertain to their vocations, they may glory and rejoice in themselves (LW, LG, 586).59 Political authorities desirous of glory should, therefore, not seek this in the mouths of other men, but in their own hearts, "which ye then do, when ye execute your office truly and faithfully". Luther adds: "So shall it come to pass, that besides the glory which ye have in yourselves, ye shall have praise and commendation also before men" (LW, LG, 586).

The implications of Luther's use of the idea of office to denote the task, function, duties and limitations of magisterial office, are many. Firstly, because on the one hand magistrates are bound to promote God's Kingdom, the official duties of the magistrate in discharging his office in a proper manner are not limited to enforcing civil

Obedience is to the "office"; to its command and its authority (see Berggrav, s.a.:306). The effect of Luther's thought, says Berggrav (at 307), is that we "are not to come to grips with an unlawfully constituted authority hesitantly, carefully, or halfway apologetically!" (Berggrav, s.a.:307).

58 LW, LG, 551: "So the ministers of the Word, the magistrates of commonweals, parents, children, masters, servants, etc. are true saints, if first and before all things they assure themselves that Christ is their wisdom, righteousness, sanctification, and redemption: secondly, if everyone do his duty in his vocation according to the rule of God's word, and obey not the flesh, but repress the lusts and desires thereof by the Spirit."

59 Such an office-bearer may then say: "I have done the works of my vocation appointed unto me by God, with such faithfulness and diligence as I was able. Therefore I know that this work, being done in faith and obedience to God, pleaseth God." 
discipline by way of punishment only (LW, LG, 203), but also to prevent scorners of the Gospel from traducing it. In his letter to Thomas Fischer, preacher in Milau, Luther wrote in 1519 that even as no one can be compelled to accept the Gospel, so no magistrate must suffer any one to traduce it. If any one does, the magistrate must have him up and admonish him and hear his reasons for acting as he does. If he can give none, then he must be bound over to silence, "so that the seeds of dissension may not be sown" (LW, L, 39:81). 60 However, no one is to be coerced in spiritual matters. 61 To the magistrate of Dantzic, Luther wrote in 1525 that each exercises "his own free will as to what he shall believe; for it is not the sword which must bear rule here, but the spirit of God" (LW, L, 116:168-9). This view does, however, not diminish the duties of magistrates towards spiritual authorities. In his Treatise on Good Works (1520) Luther addresses the problem that "spiritual magistrates" (pastors) neglect their peculiar work, namely the fostering of godliness and discipline. Kings, princes, the nobility, municipalities and communities must then begin on their own and put a check to these conditions, so that bishops and the clergy may be induced to follow, without, however, the political authorities neglecting to enact reforms in their particular spheres. All of this forms part of the works enjoined by the Fourth Commandment.62 This view forms part of Luther's wider appeal to withstand the work of the devil in society - God has ordained magistrates, elders, schoolmasters, laws and statutes "to bind the claws of the devil, and hinder him from raging and swelling so powerfully in those who are his, according to his will and pleasure" (TT, 274:140). Although magistrates and rulers may make excellent laws, they deliver no man from the curse before God. The kingdom of Babylon, ordained of God and by him committed unto kings, had excellent laws and all nations were commanded to obey them: nevertheless, obedience to the laws did not save this kingdom from the curse of the law of God: "In like manner we obey the laws

60 Letter to Thomas Fischer, preacher in Milau, dated 26 August, 1519. He adds: "For whoever will speak against it must do so openly - the magistrate being called upon to put down all private disputes with all his authority."

61 For Luther's resistance to the idea of political authorities holding power over man's conscience, see Gritsch (1972:47).

62 LW, GW, 210: "Now see, here only a few works of magistrates are indicated, but they are so good and so many, that they have superabundant good works to do every hour and could constantly serve God. But these works, like the others, should also be done in faith, yea, be an exercise of faith, so that no one expects to please God by the works, but by confident trust in His favor does such works only to the honor and praise of his gracious God, thereby to serve and benefit his neighbor." 
of princes and magistrates, but we are not therefore righteous before God ..." (LW, LG, 231). Luther's views on a magistrate's duties to restrain the wicked by applying the law, must be understood against the background of his exposition in his Galatians commentary on the double use of the law: one use of the law is civil, the other is spiritual. In the civil sphere God has ordained civil laws, "yea all laws to punish transgressions" (LW, LG, 321). The purpose of the law in the civil sphere is to bridle the wicked. Therefore God has ordained magistrates, parents, teachers, laws, bonds and civil ordinances, that if they can do no more, yet at least they may bind the devil's hands, "that he rages not in his bondslaves after his own lust." 63 This civil restraint is very necessary and appointed of God, as much for public peace as for the preservation of all things, but especially lest the course of the Gospel should be hindered by the tumults and seditions of outrageous men (LW, LG, 322). Nevertheless, the civil use of the law does not justify man (LW, LG, 322). Even if political authorities, imbued with heroic virtues, govern commonwealths excellently and perform many worthy acts for the preservation thereof, yet all these are nothing before God - all righteousness concerning the government of commonwealths, with all the obedience, execution and holiness thereof, is worth nothing before God (LW, LG, 368). All these things are nothing in comparison with the righteousness which is before God, because none of these take away sin, deliver from death, or purchase life (LW, LG, 368).

In addition to the core functions of magisterial office, Luther also identifies important secondary responsibilities to be performed by magistrates. Among these, the educative responsibilities of magisterial office are the most important: if parents neglect their duties of educating their children, it becomes the responsibility of magistrates and councilmen (LW, L, volume 4, 81).64 It therefore becomes the business of councilmen and magistrates to devote the greatest care and attention to the young. Since the property, honour and life of the whole city are committed to their faithful keeping, magistrates and councilmen would fail in their duty towards God and

63 LW, LG, 322 " $(T)$ he magistrate is present with his bonds and chains; that is to say, with his laws, binding his hands and feet, that he runs not headlong into all mischief. And, if he suffers not himself to be bridled after this sort, then he loseth his head."

64 Letter to the Councilmen of All Cities in Germany That They Establish and Maintain Christian Schools (1524). A state which has to take some of the concerns of its citizens for its own account does not thereby become sovereign in these matters. Also see Berggrav (s.a.:304). 
man if they do not seek its welfare and improvement with all their powers day and night. The welfare of a city consists not only in gathering great treasures and providing solid walls, beautiful buildings and a goodly supply of guns and armour:

Nay, where these abound and reckless fools get control of them, the city suffers only the greater loss. But a city's best and highest welfare, safety and strength consist in its having many able, learned, wise, honorable and well-bred citizens; such men can readily gather treasures and all goods, protect them and put them to a good use (LW, L, volume 4, 82).

Although parents keep their children with greater diligence and care than rulers and governors keep their subjects, and fathers and mothers are masters naturally and willingly because it is a selfgrown dominion, rulers and magistrates have a compulsory mastery, insofar as they act by force, with a prepared dominion. When father and mother can rule no more, it becomes a matter for magistrates and rulers in terms of the Sixth Commandment (TT, 765:331).

As early as 1520, in his work The Babylonian Captivity of the Church, Luther distinguished between the office and the person filling the office. He argues that although no state is well governed by means of laws, wise magistrates will rule more prosperously by natural bent than by laws. If magistrates are not wise, they will further the evil by means of laws, for they will not know what use to make of the laws nor how to adapt them to the individual case:

More stress ought, therefore, to be laid, in civil affairs, on putting good and wise men in office than on making laws; for such men will themselves be the very best laws, and will judge every variety of case with lively justice. And if there be knowledge of the divine law combined with natural wisdom, then written laws will be entirely superfluous and harmful. Above all, love needs no laws whatever (LW, volume 2, 189). 65

In his commentary on Galatians (1535), Luther reiterated his views on the person of magistrates being pleasing to God: not only the office, but also the person himself should be pleasing to God.66

65 A Prelude on the Babylonian Captivity of the Church. This does not diminish the importance of political office-bearers being wise, of courageous spirit and being able to rule alone without their councillors (TT, 761:332).

66 LW, LG, 390: "For the person is baptized, believeth in Christ, is purged in his blood from all sins, liveth in the communion and fellowship of his Church. Moreover, he doth not only love the pure doctrine of the Word, but also is glad 
When a magistrate exceeds the powers of his office, he no longer rules without the command of God: "But where more authority is assumed than God's command gives, and where the magistrate attempts to rule according to human doctrines, or the subjects seek such leadership, idolatry results and the leader assumes a new character." Luther then adds the crucial implications of exceeding the boundaries of office: "The magistrate is no longer a servant or minister, but rules arbitrarily, without command of God" (LW, S, volume 6,53$) .67$ This situation is akin to tyranny (LW, LG, 590). 68 Herewith Luther has postulated a principle of legality of dynamic proportions, providing the legal basis of resistance to tyranny.

Although crudely formulated, Luther's insight into the limits of office pertaining to magistracy was the first sincere theological effort to determine the boundaries of legally exercised political power and to open up the possibility of legitimate resistance to tyranny. It also implies that political office-bearers exceeding their authority do not discharge their office rightly (LW, LG, 203); neither do they perform works well or act faithfully to their calling (see LW, LG). The crucial issue is under which circumstances resistance to tyranny or the exercise of illegitimate power would be justified. In Luther's preface to the letter of St. Paul to the Romans, the tension between obedience and resistance becomes manifest - one should honour and obey secular authority, not because it makes people virtuous in the eye of God, but because it ensures that the virtuous have outward peace and protection and that the wicked cannot do evil in undisturbed peace and without fear. Therefore, it is the duty of virtuous people to honour secular authority, even though they do not, strictly speaking, need it (LW, PR, 16). The heart of Luther's dilemma is situated in the fact that the issue of obedience becomes an over-spiritualised matter. Luther was not able to overcome this stance, because he did not sufficiently integrate Biblical perspectives on democratic polities and legitimate resistance in the

and greatly rejoiceth when he seeth it advanced, and the number of the faithful increased."

67 Sermons on the Epistle Texts: Third Sunday in Advent on 1 Corinthians 4:1-5.

68 It is the duty of civil government to ensure order, justice and peace, so that citizens can live in freedom. If civil government exceeds these boundaries, then it becomes demonic, totalitarian (forcing its will on others) and exercises powers not awarded to them by God. Berggrav (s.a.:310): "They are "tyrants who resume new and strange powers which are theirs neither by birth nor are they granted them by God or man - powers which they have seized arrogantly and criminally." To Berggrav (s.a.:316), the implications of Luther's position are clear: "Tyranny, despotism, uncontrolled absolutism are the devil's work." 
Old Testament.69 Even the more sympathetic responses to Luther's obscure remarks on political resistance suffer from the same malady and are unable to extract a clear view on these issues from Luther's thought. 70 The addition and application of Old Testamentary perspectives on political government was mainly left to the Reformer Martyr Vermigli, who, in his commentaries on the books Judges, Samuel and Kings, highlighted the role of the political covenant in Scripture.

\subsection{Peter Martyr Vermigli's views on magisterial office in his commentary on Romans}

Marvyn W. Anderson's article "Royal Idolatry: Peter Martyr Vermigli and the Reformed Tradition" (Anderson, 1978:157-201) remains one of the standard sources on Vermigli's political views. Although Anderson deals extensively with the possible influences exerted on Vermigli by Reformational authors such as Beza, Bucer, Bullinger, Zwingli, Goodman and Ponet, he merely refers to the views of Johannes Brentz (1499-1570) on the Lutheran side (Anderson, $1978: 180,181,188)$. In his earlier work on Vermigli's political theory, Kingdon did leave room for the possibility that Vermigli had gained some of his political ideas directly from Lutheran sources (Kingdon, 1980). ${ }^{71}$ The strongest point of support for this contention Kingdon finds in the fact that Vermigli's heavy reliance on Romans 13, as interpreted by the Church Fathers, is "reminiscent" of Luther (Kingdon, 1980:XIX). The point is that the impact of Luther's political views on the early work of Vermigli is not sufficiently appreciated.72 Nowhere is this more clearly illustrated than in the structure and system of Vermigli's commentary on Romans 13.

69 E.g. in the books Judges, 1 and 2 Kings and Samuel.

70 E.g. Gritsch, 1972:37-55, at 55 merely concludes: "In this respect, Luther's notso-bold sins in the realm of political ethics are both a reminder and warning - a reminder that faith without action is dead, and a warning that action without love is idolatrous."

71 See III,XX. Although Vermigli could indirectly, via Luther, have been introduced to the thought of Chrysostom, it is also highly probable that he had direct access to Chrysostomian manuscripts during his stay with Cranmer from December 21, 1547 to late February 1548 in England (Anderson, 1988:451-469, at 456-460).

72 See Anderson (1988:451-469, at 454) for elements of Lutheran influence on Vermigli's early theological thought at his first coming to Oxford. 
One of the outstanding results of the Oxford phase of Vermigli's political theology, was his commentary on Romans 13.73 Referring to the traumatic conditions under which he spent the last years of his stay in England (1547-1553), Vermigli describes the circumstances motivating the writing of this commentary in the Epistle dedicatory to the commentary. Pondering upon "all those things which happened all that whole time that I dwelt in England", driving him to "a great and manifolde griefe", Vermigli laments the fact that "so great a multitude of godly brethren are moste cruelly for theyr holy profession put to the sworde, fire, and tormentes" (Vermigli, 1568, Preface). "(H)ardened to any new griefe", writes Vermigli, he seeks a "profitable remedy bothe for myselfe and for such like as I am" (Vermigli, 1568, Preface). Vermigli has, for a long time, experienced that it is "in vaine to hope for mannes helpe, or for ayd at the worlds hand" (Vermigli, 1568, Preface). Vermigli therefore tries to persuade others to withdraw their minds from worldly aid and to "implore the heavenly and divine helpe" (Vermigli, 1568, Preface). Heavenly aid, states Vermigli, is offered unto the oppressed in two ways: first, that the oppressed with prayers may turn unto Christ - this kind of aid and remedy is "to be sought for at God's hands against our evils, and which the holy fathers, prophets, apostles, and blessed cófessors of the Christian faith, with great fruit used in their afflictions"; the second help from God are the holy Scriptures, "which we ought alwais to have in our hands as a present remedy" (Vermigli, 1568, Preface).

Vermigli, clearly reflecting his knowledge of the commentaries on the book Romans by the Greek and Latin Fathers, as well as those by Reformers such as Philip Melanchthon, Martin Bucer, Heinrich Bullinger and John Calvin, states that although these "learned travailes" upon the epistle of Paul existed "... there was no cause ... why I shoulde take upon me tha travaile to frame a new interpretation, when as other men had in this kind of speaking sufficiently and aboundantly travayled" (Vermigli, 1568, Preface). Vermigli had decided, on the insistence of others, to make public his lectures on the book Romans while lecturing at Oxford in 1550 and

73 The political and theological circumstances in which Vermigli found himself at Oxford probably contributed to his preference for the "milder" and moderate view on political resistance contained in Chrysostom's and Luther's writings. Overell (1994:87-104, at 87) describes the conditions in which Martyr found himself upon his arrival at Oxford in early spring of 1548 as "highly explosive". For Martyr's stay in England, see Smyth (1926), McLelland (1957), Anderson (1957) and Donnelly (1976). A useful biographical source is Donelly, James III \& McLelland (1999). 
1551. His "private scholles" were thus turned into commentaries, "holpé by the old writers ... especial, and also no lesse by the new, such as I have before mencioned ..." (Vermigli, 1568, Preface). Vermigli's commentary on Romans 13 clearly reflects his preference for the "old author" St. John Chrysostom's exposition on Romans (Homilie 23) (Vermigli, 1568, Preface). Although no separate commentary on this epistle by any of the Fathers (Origin, Jerome, in part Augustine, Theodoret, Oecumenius or Theophylact) is extant, Chrysostom's comments received most of the attention by the magisterial Reformers - Vermigli being no exception.

Vermigli's treatise was the fifth Reformational commentary on Romans, after Luther (1515-1516), Bullinger (1532), Bucer (1536) and Calvin (1539). ${ }^{74}$ Like the commentaries of other magisterial Reformers, Vermigli's commentary on Romans 13 is typical of the Chrysostomian and Lutheran approach to magisterial office and the obedience due to political office-bearers. In his early works prior to 1550, Propositions from Genesis (1543) and Propositions from Exodus (1545), Vermigli already shows clear traces of Chrysostom's (and Luther's) views on magistracy. Referring to the maintenance of the holy service of God, Vermigli subscribes to the responsibility of a magistrate, that sound doctrine should be maintained within his dominion; also by arms and force he should prevent anything from being done in it which may be incompatible with the lawful service of God (23.N.11). 75 In appointing magistrates, both piety and civil duty must be considered (27.N.12). As a magistrate is commanded to punish crimes, so are the guilty commanded to bear patiently the punishment laid on them for their sins (27.N.14). When we honour princes or notable people with the respect due to them, we must be careful not to seek anything from them, unless the Word of God assures us that we may ask it from a creature (27.N.15). A magistrate is a public power established by God to help the good and punish the evil, by distributing rewards and punishments as the law appoints (37.N.2). Kingdoms and magistrates are ordained by God and are also preserved by him, "therefore they cannot be so greatly disordered and corrupted by the wicked that invade and conquer them that nothing good remains" (38.N.2). God made laws, therefore he also desires magistrates (38.N.3). A magistrate should

74 This does not take into account the notes or scholia by Zwingli and Melanchthon. After Vermigli, another commentary was published by Rodolph Gualter, minister at Zurich.

75 The system of reference to Vermigli's theses for debate at Strasbourg, 1543-5, is followed as used by Joseph C. MacLelland (1994). 
require strangers to do nothing publicly against the civil religion, even if they are of a different religion (43.N.3). The word "parents" includes schoolmasters, magistrates and ministers of the Church, because in ancient times when there were but few men, the householder performed all these duties (43.P.1).

In Vermigli's commentary on Romans the Chrysostomian and Lutheran aspects of his thought are even clearer manifest, with the resulting emphasis on obedience by subjects and the divine nature of magisterial office. After his definition of magistracy (Vermigli, 1568: fol. 426b), Vermigli indicates why it is so often stressed in the New Testament that men ought to honour magistrates (Vermigli, 1568: fol. 427a), that Christ was also subject to the powers of the world (Vermigli, 1568: fol. 427b), that the Gospel does not overthrow the governments of the world (Vermigli, 1568: fol. 427a) and that magistrates are called by the name of fathers (Vermigli, 1568: fol. $427 a)$. Under this precept of obedience to magistracy is contained all types of men (Vermigli, 1568: fol. 427a) - there being sundry kinds of power (Vermigli, 1568: fol. 427b). God, in the Old Testament, confirmed the office of magistracy (Vermigli, 1568: fol. $427 \mathrm{~b})$ and the principal functions of magistracy must be distinguished from the office as such (Vermigli, 1568: fol. 427b). God is not only the author of all public power, but also distributes kingdoms and principalities (Vermigli, 1568: fol. 428a). God sometimes even uses tyrants to execute his will (Vermigli, 1568: fol. $428 \mathrm{a}$ ), so that not only good and just princes reign by the will of the Lord, but also ungodly and wicked tyrants (Vermigli, 1568: fol. 428a). Even as kings ought to obey the word of God pronounced by the ministers of the Church, an ecclesiastical minister is not exempted from obedience and subjection to a magistrate (Vermigli, 1568: fol. 428b). The ministers of the Church ought not to usurp the functions of magistracy (Vermigli, 1568: fol. 429a). Grievous punishments are appointed to seditious and rebellious persons (Vermigli, 1568: fol. 429b), while they who obey the powers, obey God (Vermigli, 1568: fol. 429b). Even tyrants have more utility and commodity than anarchy (Vermigli, 1568: fol. 430a) and it is not lawful for private men to kill a tyrant (Vermigli, 1568: fol. 430a). A magistrate is a keeper of both the first and the second tables of the law (Vermigli, 1568: fol. 431a) and finally, princes ought to be acknowledged both as fathers and lords (Vermigli, 1568: fol. 432a).

Vermigli explicitly uses Chrysostom's interpretation of Romans 13: 
- firstly, on the issue that evangelical doctrine was not given to overthrow political constitutions, but rather to confirm and inspire them (Vermigli, 1568: fol. 427a);

- secondly, he supports Chrysostom's view that priests, monks, prophets, apostles and evangelists are all included under the general precept to be obedient to political powers (Vermigli, 1568: fol. 427a);

- thirdly, in agreement with Chrysostom, Vermigli supports the principle that no one is excepted from the universal precept that every soul must be obedient to the political authorities over them (Vermigli, 1568: fol. 427b);

- fourthly, Vermigli follows Chrysostom's distinction between the office (or principal function) and the person performing the duties of such office (Vermigli, 1568: fol. 427b);

- fifthly, Vermigli supports Chrysostom's view that good princes make virtues easy when they both urge them by example and motivate men to attain them by both fear and threat of punishment (Vermigli, 1568: fol. 431a);

- sixthly, to Vermigli, Chrysostom was correct in calling upon public powers to assist the ministers of the Church (Vermigli, 1568: fol. 431a). ${ }^{76}$

Following the Chrisostomian-Lutheran interpretation of Romans 13, Vermigli's core theme in his commentary on this passage is that subjects owe obedience to political authorities because it is a Godgiven precept.

\section{Conclusion}

Chrysostom contributed significantly towards the development of a systematic theology of political office: the gospel of Christ was not intended to overthrow the shared political arrangements (politeia), but to reform them and to teach mankind to prevent needless violence; the gospel subjected disorder to restraint and served to establish an orderly society. God made the same principle operate in our society as in our physical constitution - the parts of the body

76 Elsewhere in the same commentary, Vermigli relies on Chrysostom for the view that the devout subjects ought also to subject themselves to magistrates, "although they themselves are the children of God, and appointed to the kingdom of heaven", for their glory is not in the state of this life (432 b). He also quotes Chrysostom for support on his interpretation of Romans 13:9 to the effect that the whole law is presupposed in the brief statement of the law in this verse (433a). 
are not all equal: similarly God provided for many forms of rule, authority and subordination in relationships of man and wife, child and parent, older and younger, slave and free, ruler and ruled, etcetera. Submitting to rulers means to obey God; obedience to political rulers is not a favour, but man's duty; punishment and vindicatory justice is a virtue and a service to God that he has willed; political government fulfils God's law without necessarily being conscious of doing so, because government is highly beneficial, ensuring peace and good administration of society and insofar as the political ruler has a divine character, he is a living law.

Martin Luther, at the beginning of the Reformation, carried the Biblical perspectives on magisterial office to their logical conclusion. In his analysis of the relationship between spiritual and political government, Luther provided a refined view of the Biblical idea of office - spiritual authority in the ecclesiastical domain and political government in the political sphere are related to the various offices responsible for maintaining order in their respective fields of government.

Although Luther's political theology gradually developed towards the acceptance of the principle of political resistance, it was the Swiss Reformer, Heinrich Bullinger's application of the idea of the Biblical covenant to the political sphere that provided a more firm foundation for Reformational resistance in the political field.

\section{Abbreviations used}

$\mathrm{CR}=$ Commentary on Romans

GW = A Treatise on Good Works, together with the Letter of Dedication

$\mathrm{LC}=$ Large Catechism

$\mathrm{LG}=$ Paul's Letter to the Galatians

$\mathrm{LW}=$ Luther's Works

$\mathrm{OL}=$ An Open Letter to the Christian Nobility of the German Nation

Concerning the Reform of the Christian Estate

$\mathrm{PR}=$ Preface to the Letter of St. Paul to the Romans

$\mathrm{S}=$ Sermons

TT = Table Talk (Luther)

$\mathrm{WW}=$ Watchwords for the Warfare of Life

\section{List of references}

ANDERSON, M.W. 1973. Peter Martyr, Reformed theologian (1542-1562): His letters to Heinrich Bullinger and John Calvin. Sixteenth Century Journal, 4:41-64. 
ANDERSON, M.W. 1975. Peter Martyr: A Reformer in exile (1542-1562). A chronology of Biblical writings in England and Europe. Nieuwkoop: De Graaf.

ANDERSON, M.W. 1978. Royal idolatry: Peter Martyr and the Reformed tradition (In Hillerbrand, Hans J., ed. Archiv für Reformationsgeschichte. p. 157-200.)

ANDERSON, M.W. 1988. Rhetoric and reality: Peter Martyr and the English Reformation. Sixteenth Century Journal, 19:451-469.

ARNOBIUS. 1996. Writings. (In Ages Digital Library: The Ante-Necene Fathers. Vol. 6. Transl. by Hamilton Bryce \& Hugh Campbell. Electronic version in the Master Christian Library, version 5. Albany, Oregon: Ages Software.) (All references in this bibliography to the Ages digital library is to this source.)

AUGUSTINE. 1996a. Expositions on the Psalms. (In Schaff, Philip, ed. Ages digital library. The Post-Necene Fathers. First Series. Vol. 8.)

AUGUSTINE. 1996b. The city of God. (In Ages digital library. The Post-Necene Fathers. Vol. 2, Book II, Chapter 9. Transl. by Marcus Dodds.)

BAKER, J.W. 1980. Heinrich Bullinger and the covenant: The other Reformed tradition. Ohio: Ohio University Press.

BERGGRAV, E. s.a. Man and state. Philadelphia: Muhlenberg.

BRAVI, G.O. 2002. Über die Intellektuellen Wurzeln des Republikanismus von Peter Martyr Vermigli (In Campi, Emedio, ed., Peter Martyr Vermigli. Humanism, republicanism, reformation. Genève: Librairie Droz. p. 119141.)

CHRYSOSTOM, St. JOHN. M.DC.XCIIX. Sancti Patri Nostri Joannis Chrysostomi Archiepiscopi Constantinopolitani Opera Omnia in Duodecim Tomos distributa, Quorum Sex Priores Opuscula Ejus Varia, Sex posteriores in Novi Testament libros Homilias Complectuntur. Graece \& Latine conjunctium edidit, ex Bibliotheca Christianissimi Regis, \& melioribus undique conquisitis exemplaribus recensuit, \& Parisiis Anno MDCIX. (In lucem emisit FRONTO DUCAEUS Societatis JESU Theologus. Juxta cujus exeplar NOVA HAEC EDITIO accurate recensita, emendata, \& in arctiorem modum coacta, nunc primum in Germania prodit, cum copiosis Indicibus, \& Privilegio Serenissimi Potentissimique Regis Poliniae., Tomus Quartus (Novum Testamentum). Francofurti ad Moenum: BALTHASARIS CHRISTOPHORI WUSTII, Senioris, M.DC.XCIIX.)

CHRYSOSTOM, St. JOHN. 1996. Homilies on the Epistle of St. Paul the Apostle to the Romans. (Transl. by George B. Stevens.) (In Necene and Post-Necene fathers. Series 1, vol. 11. Albany, Oregon: Ages Software.) (Electronic Version in the Master Christian Library, Version 5.)

DAGRON, G. 1974. Naissance d'une capitale, Constantinople et ses institutiones de 330 à 451. Paris: Presse de Universitaires de France.

DIONYSIUS. 1996. Works: Extant fragments. (In Ages digital library. Vol. 6, Part 2: The Ante-Necene Fathers.)

DONNELLY, J.P. 1976. Calvinism and Scholasticism in Vermigli's doctrine of man and grace. Leiden: Brill.

DONNELLEY, J.P., JAMES III, F.A. \& McLELLAND, J.C., eds. 1994. The Peter Martyr library series. Thomas Jefferson University Press \& Truman State University Press. 
DONNELLY, J.P., JAMES III, F.A. \& McLELLAND, J.C. 1999. The Peter Martyr reader. Kirksville: Truman State University Press.

DONNELLY, J.P. \& KINGDON, R.M. 1990. A bibliography of the works of Peter Martyr Vermigli. Vol. 13. (In the series Sixteenth Century Essays and Studies. Kirksville, Missouri: Sixteenth Century Journal Publishers.)

DONNELLY, J.P. \& KINGDON, R.M. \& Anderson, M.W. 1990. A bibliography of the writings of Peter Martyr Vermigli. Kirksville: Sixteenth Century Journal Publishers.

ERASMUS. [1516] 1997. The education of a Christian prince (Transl. by and ed. by Lisa Jardine.) Cambridge: Cambridge University Press.

EUSEBIUS. 1996. Church history. (In Schaff, Philip, ed. Ages digital library: The Necene and Post-Necene Fathers. Series 2, vol. 1.)

FESTUGIÉRE, A.-J. 1959. Antioche paienne et chrétienne: Libanius, Chrysostome et le moines de Syrie. Paris: Boccard.

FIELD, F., ed. 1845-1862. Iohannis Chrysostomi interpretatio omnium epistularum Paulinarum. Oxford: s.n.

GRITSCH, E.W. 1972. Martin Luther and violence: A reappraisal of a neuralgic theme. Sixteenth Century Journal, 3:37-55, April.

IRENAEUS. 1996. Against heresies (In Ages digital library: The Ante-Necene Fathers. Vol. 1: The Apostolic Fathers: The Writings down to A.D. 325.)

JAMES III, F.A. 1998. Peter Martyr Vermigli and predestination: The Augustinian inheritance of an Italian Reformer. Oxford: Clarendon.

KELLY, J.N.D. 1995. Golden mouth: The story of John Chrysostom, ascetic, preacher, bishop. London: Duckworth.

KINGDON, R.M. 1955. The first expression of Theodore Beza's political ideas. (In Archiv für Reformationsgeschichte. Vol. 46. p. 88-100.)

KINGDON, R.M. 1980. The political thought of Peter Martyr Vermigli. Selected texts and commentary. Genève: Librairie Droz.

LUTHER, M. 1956. Luther's Works (LW). Vol. 1, 2, 4-7, 13. (In Pelikan, Jaroslav, ed. Ages digital library collection: Books for the ages version 1.0, 1997. Saint Louis: Concordia.)

LUTHER, M. 1976. Commentary on Romans (CR). (Transl. by Theodore Mueller.) Grand Rapids: Kregal.

LUTHER, M. 1996. Table Talk (TT). (In Ages digital library: The master Christian library version, 5 .)

McLELLAND, J.C. 1957. The visible words of God: An exposition of the sacramental theology of Peter Martyr Vermigli. Edinburgh: Oliver \& Boyd.

McLELLAND, J.C. 1980. Peter Martyr Vermigli and the Italian Reform. Ontario: Wilfred Laurier University.

McLELLAND, J.C. 1994. The Peter Martyr library series. Kirksville: Sixteenth Century Journal Publishers.

McNAIR, P. 1967. Peter Martyr in Italy: An anatomy of apostacy. Oxford: Clarendon.

MIGNE, J.P. 1857-1866. Homilies on the statues. Patrilogia Graeca. Vol. 49.

O'DONNOVAN, O. \& O'DONNOVAN, J.L. 1999. From Irenius to Grotius. A sourcebook in Christian political thought. Grand Rapids/Cambridge: Eerdmans.

ORIGIN. 1996. De Principiis. (In Ages digital library. Vol. 4. Fathers of the Third Century. The master Christian library version 5.)

OVERELL, M.A. 1994. Peter Martyr in England 1547-1553: An alternative view. Sixteenth Century Joural, 15:87-104. 
RITTER, A.M. 1972. Charisma im Verständnis des Johannes Chrysostom und seiner Zeit. Göttingen: Vandenhoek \& Ruprecht.

SMYTH, C.H. 1926. Cranmer and the Reformation under Edward VI. Cambridge: Cambridge University Press.

TERTULLIAN. 1996. Apologetic. Transl. by S. Thelwall. (In Roberts, A. \& Donaldson, J., ed. Ages digital library: The Ante-Necene Fathers. Vol. 1.) (The Apostolic Fathers.)

VERMIGLI, P.M. 1568. Most learned and fruitful commentaries upon the Epistle of St. Paul to the Romanes. London: John Daye.

\section{Key concepts:}

Bullinger

Chrysostom

covenant, views on

Luther

magisterial office: Vermigli's views

Vermigli: political theology

\section{Kernbegrippe:}

\section{Bullinger}

Chrysostomus

Luther

politieke owerheidsamp

verbond, sienings van

Vermigli: politieke teologie 